\title{
HEATING DEMAND IN THE RESIDENTIAL SECTOR: TACKLING THE ENIGMA OF LOW PRICE ELASTICITY OF HOMEOWNERS' EXPENSES ${ }^{1}$
}

\author{
Ines Weber and Bernhard Gill
}

\author{
Institute of Sociology \\ Ludwig Maximilian University of Munich \\ Professor-Huber-Platz 2, 80539 Munich \\ e-mail: Ines.Weber@soziologie.uni-muenchen.de
}

\begin{abstract}
This paper presents findings from our study which explored the price elasticities for domestic space heating energy of households in Germany. We focus upon the difference in price elasticities between homeowners and tenants found in previous studies in order to further elaborate on this. Using panel data from the GSOEP we perform fixed effects and OLS regressions to examine the influencing factors yielding the difference in heating price elasticities between homeowners and tenants. Our results suggest that the difference in the heating price elasticities is to a great extent the result of differing initial consumption levels from homeowners and tenants.

Understanding the reactions of households to rising energy prices according to various household types and initial levels of consumption and expenses is helpful in designing more target-oriented policy measures in order to reduce CO2 emissions. We show that per capita heat energy consumption is highest for homeowners of detached buildings which has increased in the past few years rather than decreased. This leads to lower price elasticities for homeowners in comparison to tenants. Reduction policies thus should have a stronger focus on the group of homeowners of detached buildings
\end{abstract}

Keywords: space heating, price elasticity, Germany, principal-agent theory, saving incentives, refurbishment incentives

\section{INTRODUCTION}

The residential sector plays an important role in the German government's goal to reduce $\mathrm{CO}_{2}$ emissions to the amount of $80-90$ per cent by the year 2050 relative to 1990 . This is because the household energy demand for space heating accounts up to $70 \%$ of the total energy demand of households (BMWi, 2014). Prices for energy in the residential sector have increased, which raises the question whether this trend will lead to households consuming less energy and thus reducing $\mathrm{CO}_{2}$ emissions in the residential sector.

1 This research project was funded by the Federal Ministry of Education and Research as part of the funding priority "Research for Sustainable Development" (FONA) with the project "Lokale Passung". 
In order to tackle this question, this paper presents the findings of energy price elasticities for domestic space heating in Germany. Building on previous research on energy prices and income elasticities for domestic space heating (Baker et al., 1989; Guertin et al., 2003; Nesbakken, 1999, 2000; Halvorsen and Larsen, 2001; Hanemann et al., 2013; Madlener and Hautermann, 2011; Meier and Rehdanz, 2010), we will focus on the differences in heating price elasticities between homeowners and tenants which were found to exist, but which to date were not investigated in more detail. More specifically, tenants showed larger heating price elasticities than owners (Madlener and Hauertmann, 2011; Meier and Rehdanz, 2010).

The objective of this study is to (1) explain why this finding is counterintuitive at first glance, (2) discuss possible explanations for this finding, and (3) test the derived hypotheses with fixed effects and OLS regressions. This article contributes to the already existing research on the topic in the following way: a) it supports the observation that owners have lower price elasticities; b) beyond the existing literature, it explains why, from a principal-agent theory perspective, this finding is rather surprising; and finally c) it tries to elucidate the causes behind the rather odd observation. Our more detailed findings suggest that higher levels of energy expenditures and the building specificities of apartment blocks engender higher price elasticities, while higher levels of domesticity result in lower elasticities. The first two characteristics are often found in tenant households while the latter more often corresponds with owner households. Our empirical analysis is performed with data from the German Socio-Economic Panel (GSOEP) for the period 1998 to 2013.

The study is structured as follows: In section 2 we discuss why, from a microeconomic point of view, one would expect higher elasticities for homeowners instead of tenants. In addition, possible explanations for the lower elasticity of homeowners are discussed and hypotheses are derived. Section 3 describes the data used and the methodology employed for the empirical analysis, and section 4 presents the results of the empirical analysis, both the fixed effects regression results as well as the OLS regression results. In the final section, the empirical results are summarized in order to discuss policy implications.

\section{THEORY}

Although oil prices have been decreasing in the past three years, energy prices overall and thus heating costs for households have been increasing. At the same time the net equivalence income of households has increased at a much slower rate. For example, between 1995 to 2013 in Germany the costs for domestic fuel have risen about 150\% (domestic fuel oil) and 75\% (natural gasoline, district heating), whereas the net equivalence income of households has only increased about $40 \%$ during the same period (BMWi, 2014; Eurostat, 2016).

Households thus have to spend a higher share of their income for energy than in the past, leading to a larger amount of households facing fuel poverty (Wolff et al., 2017). How do households react to this development? We discuss possible reactions below. 
First, it is possible that households do not react at all to rising energy prices. In line with Ernst Engel's law (Engel, 1881) and the fact that heating is not easy to substitute, a warm home could be regarded as a necessity good. If, however, households do think about reducing their heating costs, they need to decrease the amount of energy needed. This can be achieved by reducing the indoor room temperatures. Also, reducing the frequency or length of ventilation leads to less heating energy being lost to the atmosphere, i.e. out of the home. Furthermore, investing in more energy efficient technology reduces heating costs. This investment, however, is in conjunction with high expenses when the technology is installed. Also, the payback period for the investment varies according to the energy price trend, which causes uncertainty with regard to the rationality of the investment.

In general, the reaction of a household to rising energy prices can be described with the price elasticity of demand. It is defined to be the percent change in quantity divided by the percent change in price: $\varepsilon_{\mathrm{i}}=$ "\% Change in quantity " $/$ "\% Change in price" (Varian, 2010).

It cannot be expected that all households react to rising energy prices in the same way. Not only does the individual comfort temperature vary to a large extent but reducing room temperature affects people more or less strongly (Wolff et al., 2017). Especially since the different elasticities for homeowners and tenants ${ }^{2}$ in previous research suggest that motivation and freedom of action differ in the population and between certain groups. Theoretically, it could be expected that homeowners react much more sensitively to increasing heating prices than homeowners. This will be laid out in more detail hereafter.

One important factor influencing the reaction of a household is transparency and timing of heating bills. From a microeconomic point of view, households that have a good overview of their heating costs and have direct feedback can estimate the financial benefit from reducing the room temperature or investing in newer technologies more precisely. Homeowners receive more direct feedback than tenants, thus they should be better motivated to reduce heating consumption.

In addition, tenants in Germany partly pay heating costs independently of their own consumption as they pay $30-50 \%$ of the buildings' heating costs allocated by the size of the tenants' dwelling in square meters. This generates the microeconomic effect that reducing the indoor room temperature is more profitable for homeowners than for tenants. Again, homeowners should have higher elasticities.

In line with E. Engel's, respectively Hermann Schwabe's law, those households that have to spend a larger share of their income for heating should have the largest elasticities (Engel, 1881; Schwabe, 1966). As owners in Germany frequently inhabit detached buildings (RWI, 2013) and detached buildings have higher consumption per square meter due to a larger surface-to-volume ratio (sa:v) (Bettencourt et al., 2007; Schubert et al., 2012), we expect homeowners to spend larger shares of their income for heating.

2 When talking about homeowners and tenants, we mean homeowners living in their own home and tenants living in a rented apartment or house. 
However, when it comes to increasing heating energy efficiency, affluent homeowners can make the choice to invest in energy efficient technology or make their building more energy efficient by exchanging old windows or insulating the building's roof or outer walls. With tenants, a principal-agent problem between the tenants (principal) and landlords (agent) arises. The agent is able to make decisions that impact the principal: It is the landlord's decision whether a new heating system or new windows are installed in rented flats. In the case where the landlord does not invest, the tenant is left with reducing the indoor temperatures if lower heating costs in the apartment are sought. ${ }^{3}$ That is, homeowners have more opportunities to invest in the energy efficiency of their home or heating systems as there is no principal-agent problem. Furthermore, the tenant cannot invest in profound energy saving refurbishment while the owner has no strong incentive to invest in rented apartments since the tenant reaps most of the profit of the energy savings (Kossmann et al., 2016).

The aspects laid out above implicate that homeowners should have larger elasticities than tenants. This is also our first hypothesis. However, as previous studies showed, homeowners in fact have lower elasticities than tenants. In the next part we will therefore discuss possible explanations for this discrepancy by laying out other factors influencing the price elasticity of a household independent of the ownership structure.

First, households with high levels of energy consumption in $\mathrm{kWh}$ per square meter have better reduction potentials. In line with the law of diminishing marginal utility and $\mathrm{H}$. H. Gossen's First Law, the first unit in a consumption decrease yields more utility for households than subsequent units (Gossen, 1854). Already economizing households have a harder time when seeking to further reduce energy consumption. Therefore, we expect households with high initial consumption levels to have higher price elasticities (hypothesis 2).

Similarly, conforming to Engel's law, low income households have to spend higher shares of their income for heating energy, as heating energy is indispensable and hard to substitute in rather cold countries like Germany. Those households with higher levels of energy expenditures are under higher economic pressure for reduction than households which need to spend a smaller share of their income for heating energy. Hence we expect households spending higher shares of their income for heating to have higher elasticities (hypothesis 3).

We further postulate the effect of domesticity: in family or pensioner households one can assume that the inhabitants are at home more often and longer than a household with a single working person. The energy consumption of households fluctuates with the life cycle and associated daily schedules of household members. Whereas a family with small children has high energy consumption, households consisting of young working inhabitants have low levels of energy consumption (Van Raaij, and Verhallen, 1983). Likewise, as there is no need to heat an apartment or house to a high tempera-

3 Relocating due to high heating costs in Germany is mostly uneconomic due to price regulations which hamper rent increases during existing contracts. 
ture if nobody is at home, households with lower levels of domesticity can reduce their heating demand by heating less during their absence by relying, for example, on timer switches. Households with children or elderly persons with high levels of domesticity however cannot reduce the heating demand without having to accept lower indoor temperatures, i.e. a loss in comfort. We therefore postulate that high levels of domesticity result in households reacting less to heating energy price increases (hypothesis 4).

Further, we hypothesize that the difference in elasticities between homeowners and tenants can be attributed to different building types. As tenants live in residential buildings and homeowners inhabit detached buildings for the most part, we postulate that the difference in elasticity between homeowners and tenants is rather the effect of these building types. More specifically, we expect that inhabitants of large residential buildings have the highest elasticities as it is easier to economize in large residential buildings which cool down much slower than detached houses due to a better sa:v ratio (hypothesis 5).

After a description of the data used and the statistical methods employed in the next section, heating price elasticities are computed and the hypotheses derived above will be tested in section 4 .

\section{DATA \& METHODOLOGY}

For this study data was drawn from the German Socio-Economic Panel (GSOEP) to examine heating price elasticities for households in Germany. This longitudinal panel data set, initiated in 1984, contains data at the individual and household level. Although the GSOEP data was available long before 1998, the data was limited as the households' heating type was surveyed for the first time in 1998. For the analysis, the majority of data is derived from the household questionnaire. Additionally, some relevant variables from the individual questionnaire were merged with the household data. We further expanded the GSOEP data with publicly available data: heating degree days for Germany (Eurostat, 2016) in order to control for climatic effects between years, and annual energy prices for Germany according to the heating type, namely oil, gas, district heating and electricity (BMWi, 2014).

A limitation of the data used in this study is that it does not include measures for heating consumption. Instead, only annual heating costs are surveyed. Therefore, costs were converted into heating consumption by dividing the reported costs with the annual energy prices with respect to the type of heating. This procedure leads to inaccurate values, as it is not distinguishable if additional payments by tenants are included or if homeowners buy a larger amount of oil when it is cheaper or a smaller amount when it is expensive. Moreover, energy prices also differ across Germany.

Particular attention is also paid in the case of households relocating. As a relocation is immediately connected with changes in the energy demand of homes, this case needs to be avoided because it would distort the price elasticity of the households. In the 14 years included in this panel, the relocation of households is not unlikely. However, excluding these households would result in massive data loss. Therefore, relocated households are assigned a new household ID after a relocation, thus they are treated as a new case. 


\subsection{Panel data set}

After excluding implausible values with respect to the heating consumption, living space and household income, the panel data set consists of 102808 observations. A panel data set makes the application of a panel data regression model, in this case a fixed effects regression, reasonable. A fixed effects model is particularly suited here as it controls for unobserved heterogeneity between households (Wooldridge, 2013). ${ }^{4}$ Table 1 gives an overview of the variables included in the fixed effects regressions. The net equivalence income is computed with the square root scale used in recent OECD publications (OECD, 2012).

Table 1. Definition of variables and descriptive statistics: panel data set (GSOEP, 2015)

\begin{tabular}{|l|c|c|c|}
\hline \multicolumn{1}{|c|}{ Variable definition } & Variable name & Mean & SD \\
\hline $\begin{array}{l}\text { Annual heating energy consumption incl. domestic } \\
\text { hot water in kWh }\end{array}$ & Q & 19444 & 10742 \\
\hline Energy price in cent/kWh & EP & 6.33 & 4.04 \\
\hline Monthly net equivalence income in $€$ & NEI & 1577 & 1152 \\
\hline Household size & HHS & 2.4 & 1.2 \\
\hline Heating degree days & HDD & 3066.52 & 193.84 \\
\hline
\end{tabular}

The analyses and results in this study are divided into two parts. In the first part (4.1), price elasticities of demand are computed with fixed effects models by using the double logarithmic function, e.g. taking the logarithm of the energy consumption and the energy price (Wooldridge, 2013; Madlener and Hauertmann, 2011; Baker et al., 1989). The influence of the economies of scale effect is also important when it comes to heating energy consumption. Smaller households have lower overall, but higher per capita consumption. Referring to Nässén, the square root of the household size therefore is taken into the regression (Nässén, 2014).

The heating energy price elasticity in the fixed effects model with robust standard errors is specified as follows:

$\log \left(\mathrm{Q}_{\mathrm{it}}\right)=\beta_{0}+\beta_{\mathrm{EP}} \cdot \log \left(\mathrm{EP}_{\mathrm{it}}\right)+\beta_{\mathrm{NEI}} \cdot \log \left(\mathrm{NEI}_{\mathrm{it}}\right)+\beta_{\mathrm{HDD}} \cdot\left(\mathrm{HDD}_{\mathrm{it}}\right)+\beta_{\mathrm{HHS}} \cdot\left({ } \mathrm{HHS}_{\mathrm{it}}\right)+\alpha_{\mathrm{i}}+u_{\mathrm{it}}$ with $i=1, \ldots, N$ households and $t=1, \ldots, T$ time periods. As time-constant variables cannot be controlled for in the fixed effects model, separate regressions for homeowners and tenants as well as for different building types and household types are performed. Four building types were distinguished: detached houses, semidetached houses, residential buildings with 3-8 flats, and residential buildings with more than 9 flats. The household types consist of single-person households, family households, and households consisting of two persons. Regarding the distribution of tenants and homeowners, the GSOEP shows that homeowners to a great extent occupy detached houses whereas

4 The Hausman specification test favours the fixed effects model over the random effects model. 
tenants for the most part live in residential buildings. In addition, homeowners respectively occupants of detached houses are often families or pensioners. The share of families living in detached houses adds up to $65 \%$, whereas only about $25 \%$ of singles under the age of 60 live in detached houses. Looking at the ownership structure, about $60 \%$ of the families and $41 \%$ of pensioners living alone are owners, whereas singles under the age of 60 are tenants with a share of nearly $82 \%$ (GSOEP, 2015).

\subsection{Cross-sectional data set}

In order to control for time-invariant variables subsequent to the fixed effects regression, the panel data set is reduced to a cross-sectional data set to perform an OLS regression in section 4.2. The ambition of the OLS regression is to control for time-invariant variables in order to further examine the differences in price elasticities between homeowners and tenants. For each household a price elasticity with respect to the household's heating system is computed by dividing the quantity changes averaged over three years with the price changes averaged over three years. Three year averages were used, as this reduces the likelihood that single very low or very high consumption distorts the household's consumption.

By conflating time and excluding households not long enough in the panel (minimum 3 years), the original size of observations in the panel data set is reduced from 102808 to 4235 observations.

More time-invariant variables have been included in the OLS regression. In order to control for domesticity, we include the household's electricity costs, assuming that high electricity costs imply regular presence in the household. The household size is also included as we suppose that the likelihood of persons being present in the household increases with the household size. The heat energy consumption per $\mathrm{m}^{2}$ in $\mathrm{kWh}$ was computed by calculating the mean of the first three panel years of heating energy consumption. The underlying assumption is that households with high initial heating consumption have better reduction potentials. Similarly, the share of energy expenses of the household's budget was computed by averaging over the first three panel years in which the household was present. Besides the variables listed in Table 2, the building and heating type have been included as dummy variables in the OLS regressions.

Table 2. Definition of variables and descriptive statistics: OLS data set (GSOEP, 2015)

\begin{tabular}{|l|c|c|c|}
\hline \multicolumn{1}{|c|}{ Variable definition } & Variable name & Mean & SD \\
\hline Price elasticity & PE & -0.14 & 0.47 \\
\hline Living space in $\mathrm{m}^{2}$ & Space & 107.5 & 43.1 \\
\hline Monthly electricity expenditures in $€$ & Electricity & 68.9 & 27.2 \\
\hline $\begin{array}{l}\text { Mean heat energy consumption } / \mathrm{m}^{2} \text { in } \mathrm{kWh} \text { first 3 } \\
\text { panel years }\end{array}$ & Consumption & 215.3 & 94.6 \\
\hline $\begin{array}{l}\text { Mean energy expenses/household budget in } € \text { first 3 } \\
\text { panel years }\end{array}$ & Expenses & 0.05 & 0.03 \\
\hline
\end{tabular}


The price elasticity in the cross-sectional data set is -0.14 . Figure 1 displays a wide range of price elasticities for households and one can immediately see that many households even have positive price elasticities, i.e. as prices rise, heating consumption rises.

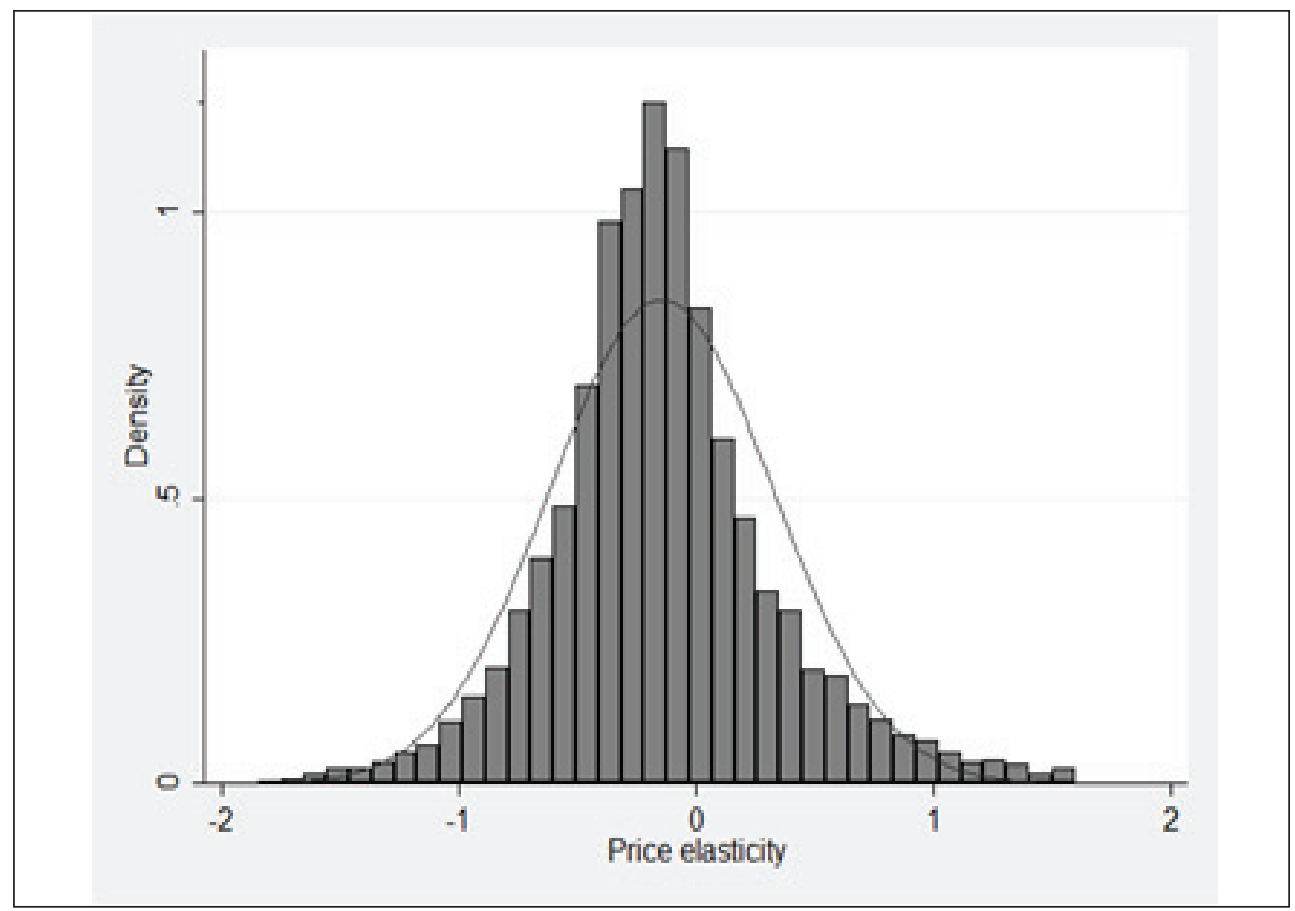

Figure 1. Histogram of the space heating price elasticity of households (GSOEP, 2015)

Although this is not to be expected from a theoretical point of view, several factors could contribute to this result. For instance, the birth of a child frequently increases energy consumption just as one's retirement increases energy consumption caused by higher domesticity levels.

Table 3. Correlation table of relevant variables in cross-sectional data set (GSOEP, 2015)

\begin{tabular}{|c|c|c|c|c|c|c|c|c|c|}
\hline & $\underline{\mathrm{PE}}$ & Tenant & $\underline{\mathrm{HHS}}$ & NEI & Space & Build. & Electr. & Cons. & Expens. \\
\hline PE & 1.0000 & & & & & & & & \\
\hline Tenant & $-0.0711^{* * *}$ & 1.0000 & & & & & & & \\
\hline$\underline{\mathrm{HHS}}$ & $0.0255^{*}$ & $-0.2310^{* * *}$ & 1.0000 & & & & & & \\
\hline NEI & -0.0168 & $-0.2301^{* * *}$ & -0.0205 & 1.0000 & & & & & \\
\hline Space & $0.0442^{* * *}$ & $-0.5350^{* * *}$ & $0.3780^{* * *}$ & $0.4019^{* * *}$ & 1.0000 & & & & \\
\hline Build. & $-0.0762^{* * *}$ & $0.6154^{* * *}$ & $-0.2534^{* * *}$ & $-0.1345^{* * *}$ & $-0.5201^{* * *}$ & 1.0000 & & & \\
\hline Electr. & $0.0918^{* * *}$ & $-0.3168^{* * *}$ & $0.5487^{* * *}$ & $0.1919^{* * *}$ & $0.4606^{* * *}$ & $-0.3846^{* * *}$ & 1.0000 & & \\
\hline Cons. & $-0.2837^{* *}$ & $0.1384^{* * *}$ & $-0.0909^{* * *}$ & $-0.1009^{* * *}$ & $-0.3182^{* *}$ & $0.0581^{* * *}$ & $-0.0420^{* * *}$ & 1.0000 & \\
\hline Expens. & $-0.1725^{* *}$ & $-0.0259^{*}$ & $0.1758^{* * *}$ & $-0.4407^{* *+}$ & 0.0063 & $-0.1687^{* * *}$ & $0.1310^{* * *}$ & 0.3555 & $1.0000^{*}$ \\
\hline
\end{tabular}

$p<0.05,{ }^{* *} p<0.01,{ }^{* * *} p<0.001$ 
Furthermore, it is a fact that households have difficulties when it comes to understanding and documenting expenses and consumption for electricity and heating, meaning that erratic values cannot be ruled out (RWI, 2013). Table 3 shows the correlation table from the cross-sectional data set for relevant variables used in the OLS regressions.

\section{RESULTS}

\subsection{Fixed effects regression results}

First we present space heating price elasticities which were computed according to the model introduced in section 3. We calculate the fixed effects model for all households and for homeowners and tenants separately, as this effect is of particular importance here.

Table 4. Fixed effects regression model: Space heating energy price elasticities (GSOEP, 2015)

\begin{tabular}{|l|c|c|c|}
\hline Dep. Var.: $\log$ Q & All & Owners & Tenants \\
\hline Log EP & $-0.313^{* * *}$ & $-0.257^{* * *}$ & $-0.421^{* * *}$ \\
\hline & $(-43.95)$ & $(-30.00)$ & $(-34.42)$ \\
\hline Log NEI & $0.0363^{* * *}$ & $0.0365^{* * *}$ & $0.0350^{* *}$ \\
\hline & $(5.43)$ & $(4.32)$ & $(3.25)$ \\
\hline HHS & $0.0919^{* * *}$ & $0.0976^{* * *}$ & $0.106^{* *}$ \\
\hline & $(7.38)$ & $(6.16)$ & $(5.22)$ \\
\hline HDD & $0.0000608^{* * *}$ & $0.0000899^{* * *}$ & 0.0000181 \\
\hline & $(10.69)$ & $(13.54)$ & $(1.79)$ \\
\hline Constant & $4.365^{* * *}$ & $4.267^{* * *}$ & $4.592^{* * *}$ \\
\hline & $(72.46)$ & $(55.51)$ & $(48.41)$ \\
\hline Observations & 98052 & 53357 & 44695 \\
\hline Adjusted $R^{2}$ & 0.056 & 0.054 & 0.065 \\
\hline
\end{tabular}

$t$ statistics in parentheses

${ }^{*} p<0.05,{ }^{* *} p<0.01,{ }^{* * *} p<0.001$

The space heating price elasticity for all households in our model is -0.31 . This result is comparable to other studies from various countries which report price elasticities for heating energy in the range of -0.15 to -0.5 (Baker et al, 1989; Guertin et al. 2003; Halvorsen and Larsen, 2001; Hanemann et al., 2013; Nesbakken, 2001).

Also in line with the results from previous studies, we find higher heating energy price elasticity for tenants with a coefficient of -0.421 in comparison to owners with a price elasticity of -0.257 . The household income elasticity amounts to 0.036 for homeowners and 0.035 for tenants. Our first hypothesis thus has to be rejected: tenants have higher elasticities than owners. Madlener and Hauertmann (2011) reported price elasticities of -0.39 for tenants and -0.12 for owners. Although the authors used the GSOEP data as well, not only their considered time period but also their model specification differs to some extent from the approach in this study, which explains the differences in the price 
elasticities. Meier and Rehdanz (2010) found even greater differences between tenants and homeowners with British household data, more precisely an elasticity of -0.19 for owners and -0.64 for tenants in the period of 1991 to 2005. In principle, our price elasticity measures are thus comparable to the results from other research, as the finding always is that tenants have much higher price elasticities than owners. ${ }^{5}$

As laid out in section 2, homeowners and tenants are unequally distributed to different building types, with tenants living more often in residential buildings while owners prevalently occupy detached houses. Moreover, homeowners and tenants are unequally distributed to different household types, with single-person households living mostly in rented apartments. We therefore postulated an influence on the price elasticity of households according to the inhabited building type and to domesticity (hypotheses $4 \& 5$ ). First, the correlation table (Table 3) shows that the coefficient for the household size is positive, meaning that an increase in the household size within the household decreases the price elasticity. This finding points towards the domesticity hypothesis, as the chance for high presence in the household increases with household size. Next, elasticities are computed for different household types in order to further test the domesticity hypothesis. We run the regression for three household types, namely single person, couples and family households. The resulting price elasticities are summed up in Table 5.

Table 5. Fixed effects regression results: space heating energy price elasticities: household types (GSOEP, 2015)

\begin{tabular}{|l|c|c|c|}
\hline Household type & Single-person & Couples & Family \\
\hline Price elasticity & -0.384 & -0.309 & -0.263 \\
\hline
\end{tabular}

In line with our fourth hypothesis (high levels of domesticity reduce a household's price elasticity), the price elasticities reported in Table 5 vary between different household types. It is apparent that the household type influences the extent of households reacting to price changes: whilst families were found to have the lowest price elasticity, persons living alone have the highest price elasticity. Next we test whether the difference in the price elasticity for owners and tenants as well as for the different household types is also reflected in the building types (hypothesis 5).

Table 6. Fixed effects regression results: space heating energy price elasticities: building types (GSOEP, 2015)

\begin{tabular}{|l|c|c|c|c|}
\hline Building type & $\begin{array}{c}\text { Detached } \\
\text { house }\end{array}$ & $\begin{array}{c}\text { Semidetached } \\
\text { house }\end{array}$ & $\begin{array}{c}\text { Residential building } \\
\text { (3-8 flats) }\end{array}$ & $\begin{array}{c}\text { Residential building } \\
\text { (>9 flats) }\end{array}$ \\
\hline Price elasticity & -0.251 & -0.260 & -0.415 & -0.429 \\
\hline
\end{tabular}

5 The minor differences in the magnitude result from the volatility of heating expenditures in the GSOEP. Thus slight differences in the model specification or in the chosen time frame have some impact. 
The regression results of the fixed effects regression summed up in Table 6 for four different building types corroborate the supposition that the different price elasticities for homeowners and tenants could be an effect of the building types inhabited by the two groups. As the regression results show, price elasticity is lowest for detached houses and highest for residential buildings with more than 9 flats. Moreover, one can see the overall trend that the household price elasticity rises with the size of the inhabited building. To conclude, based on the fixed effects regression analysis, the first hypothesis must be rejected: in line with the studies from Madlener and Hauertmann (2011) and Meier and Rehdanz (2010), homeowners indeed have lower elasticities. The fourth and fifth hypothesis, however, cannot be rejected. Household size and household type, i.e. indicators for domesticity, seem to have a significant influence on the price elasticity of households. Moreover, the effect with regard to the price elasticity according to the building type is obvious, so that the difference in the price elasticity between homeowners and tenants could simply be the effect of the inhabited building types.

The fixed effects model specification, however, is not eligible when one wants to control for time-invariant variables in a regression, such as building or often also household types. In order to check the robustness of the results obtained above and test the other formulated hypotheses, we transformed the panel data set to a cross section data set and performed OLS regressions.

OLS regression results

The mean price elasticity computed in the cross-sectional data set is lower than the price elasticity computed with the fixed effects model for the panel data set. The fixed effects regression computes the price elasticity on the household level, thus the change in heat energy consumption and energy costs for the specific timeframe. By dividing the quantity change with the price change for each household we approximately replicated the fixed effects regression. However, whereas the fixed effects regression includes every year into the computation, we used three-year averages for the calculation in Stata. This varying procedure most likely leads to the differing price elasticities. However, when looking at the price elasticity separately for tenants and owners, the difference between this groups still exists. The price elasticity for owners is with a mean of -0.12 lower than the price elasticity for tenants with an average of -0.19 . Regarding the following OLS regressions, the wide range of household price elasticity, i.e. the dependent variable, results in a rather low R-squared. Low correlations between the dependant variable and the independent variables used for the OLS regressions can already be seen in the correlation table (Table 3). We attribute the high variation in the price elasticity partly to the fact that we used heating costs reported by the households to compute consumption instead of gathered measures for the actual heating consumption. Although this is regrettable, no panel dataset exists with this information for German households. The OLS regression models were calculated with robust standard errors. Explanatory variables were added in a stepwise procedure in order to test the formulated hypotheses. Table 7 shows the regression results for five model specifications. 
Table 7. OLS regression model (GSOEP, 2015)

\begin{tabular}{|c|c|c|c|c|c|}
\hline $\begin{array}{l}\text { Dep. Var.: Price } \\
\text { elasticity }\end{array}$ & (1) & (2) & (3) & (4) & (5) \\
\hline \multirow[t]{2}{*}{\begin{tabular}{|l|} 
Tenant, Ref: \\
Owner \\
\end{tabular}} & $-0.0731^{* * *}$ & $-0.0415^{* *}$ & $-0.0651^{* * *}$ & $-0.0405^{*}$ & -0.0259 \\
\hline & $(-4.54)$ & $(-2.69)$ & $(-4.11)$ & $(-2.49)$ & $(-1.17)$ \\
\hline \multirow[t]{2}{*}{ NEI } & $-0.0000155^{*}$ & $-0.0000251^{* * *}$ & $-0.0000541^{\cdots *}$ & $-0.0000717^{*+*+}$ & $-0.0000401^{*+*}$ \\
\hline & $(-2.08)$ & $(-3.36)$ & $(-5.96)$ & $(-7.52)$ & $(-3.95)$ \\
\hline \multirow[t]{2}{*}{ Consumption } & & $-0.00142^{* * *}$ & $-0.00117^{* * *}$ & $-0.00116^{* * *}$ & $-0.00165^{* * *}$ \\
\hline & & $(-17.03)$ & $(-12.50)$ & $(-12.25)$ & $(-14.25)$ \\
\hline \multirow[t]{2}{*}{ Expenses } & & & $-2.355^{\ldots * *}$ & $-2.777^{* * *}$ & $-1.909^{\cdots * *}$ \\
\hline & & & $(-6.60)$ & $(-7.54)$ & $(-4.69)$ \\
\hline \multirow[t]{2}{*}{ HHS } & & & & $-0.108^{* * *}$ & $-0.0846^{* *}$ \\
\hline & & & & $(-4.09)$ & $(-3.21)$ \\
\hline \multirow[t]{2}{*}{\begin{tabular}{|l} 
Electricity \\
\end{tabular}} & & & & $0.00287^{* * *}$ & $0.00297^{* * *}$ \\
\hline & & & & $(8.32)$ & $(8.34)$ \\
\hline \multirow[t]{2}{*}{ Space } & & & & & $-0.00173^{* * *}$ \\
\hline & & & & & $(-6.67)$ \\
\hline \multicolumn{6}{|c|}{ Building type, Ref: detached house } \\
\hline \multicolumn{2}{|c|}{ Semidetached house } & & & & $-0.0701^{* * *}$ \\
\hline & & & & & $(-3.71)$ \\
\hline \multicolumn{2}{|c|}{ Residential building 3-8 flats } & & & & $-0.0895^{* * *}$ \\
\hline & & & & & $(-3.76)$ \\
\hline \multicolumn{2}{|c|}{ Residential building $>9$ flats } & & & & $-0.130^{* * *}$ \\
\hline & & & & & $(-4.18)$ \\
\hline \multicolumn{6}{|c|}{ Heating type, Ref: Oil } \\
\hline \multirow[t]{2}{*}{ Gas } & & & & & $-0.0552^{* * *}$ \\
\hline & & & & & $(-4.05)$ \\
\hline \multirow[t]{2}{*}{ District heating } & & & & & -0.0316 \\
\hline & & & & & $(-1.08)$ \\
\hline \multirow[t]{2}{*}{ Electric heating } & & & & & $-0.169^{* * *}$ \\
\hline & & & & & $(-3.63)$ \\
\hline \multirow[t]{2}{*}{ Constant } & $-0.0932^{* * *}$ & $0.217^{*+*}$ & $0.347^{* * *}$ & $0.355^{* * *}$ & $0.594^{* * *}$ \\
\hline & $(-6.12)$ & $(8.51)$ & $(11.44)$ & $(7.75)$ & $(11.63)$ \\
\hline Observations & 3994 & 3994 & 3994 & 3994 & 3994 \\
\hline Adjusted $R^{2}$ & 0.005 & 0.083 & 0.097 & 0.114 & 0.128 \\
\hline
\end{tabular}

$t$ statistics in parentheses

" $p<0.05, ", p<0.01, "{ }^{\prime \prime \prime} p<0.001$ 
Model 1 tests if a difference exists in the price elasticity between owners and tenants, whilst income is controlled for. Here, the difference between homeowners and tenants heating price elasticity is significant $(\mathrm{p}<0.001)$. Just like in the fixed effects model, tenants have higher price elasticity than owners, the first hypothesis (owners have higher elasticities than tenants) thus has to be rejected.

As we postulated that the price elasticity is dependent on the initial heat consumption of a household, we included the amount of heat consumption in $\mathrm{kWh}$ from the first three years in which the household was present in the panel in model 2. The effect of the household's initial energy consumption is negative. Thus, the higher the initial heat energy consumption of the household at the beginning of the panel, the higher its price elasticity. This finding supports our second hypothesis, according to which households with high initial consumption levels have higher price elasticities.

It bears mentioning that the R-squared of the model increases heavily when the initial heat consumption is included into the model. Also, the difference in the price elasticity between tenants and homeowners becomes smaller. In model 3 we further include the variable for the household's expenses in order to test our third hypothesis, i.e. that households spending a higher share of their income for heating have higher elasticities. The negative coefficient for the heating expenses of households indicates that high initial energy expenses indeed give rise to higher price elasticities.

Model 4 shows what happens to the difference in price elasticity if indicators for the household's domesticity, i.e. the household size and the electricity costs, are included. The difference in price elasticity between tenants and owners becomes smaller and it is now only significant on the $5 \%$ level of confidence. The positive coefficient for the electricity costs implies that high electricity costs come along with lower price elasticities, which supports the fourth hypothesis, namely that high domesticity results in lower price elasticities. The effect for the household size is negative, which is rather counterintuitive as we postulated the domesticity effect and one could suppose that domesticity rises with the household size. Here, the electricity costs most likely already control for the household size and domesticity, as the household size has a positive coefficient in the correlation table (Table 3), and the regression from model 4 without the electricity costs of the household yields a positive effect of the household size as well (not shown in Table 7). To test the building type hypothesis, building type, living space and fuel type are included to the regression in our last model. The negative coefficient for the household's living space indicates that the larger the living space, the higher the price elasticity. This is because large living spaces allow for more possibilities to reduce room temperatures in parts of the dwelling. Furthermore, the building type itself has a significant effect: just like in the fixed effects regressions (Table 6), the higher the price elasticity is, the more compact the occupied building is. The coefficients for the heating type show that the price elasticity is lowest for households heating with oil. Although we cannot test this with the data available to us, this finding could be due to the fact that households heating with oil have a rather low level of feedback as there is no metering in $\mathrm{kWh}$. Further, houses which are heated with oil are mostly older detached houses, which cool down 
faster than newer compact buildings, thus limiting the energy consumption reduction potential.

Finally, the difference in the price elasticity between homeowners and tenants is now no longer statistically significant. We can therefore conclude that the difference in elasticities between homeowners and tenants nearly vanish when we control for the initial level of energy consumption, the magnitude of the household's heating energy expenses in the first three panel years, the household's domesticity measured by electricity costs, and building type characteristics.

The decisive factor according to the high t-statistic and the jump in the coefficient of determination is the household's initial level of consumption in model 2. We therefore look at this variable more precisely. Figure 2 shows that the price elasticity increases with the initial level of the household's heating consumption.

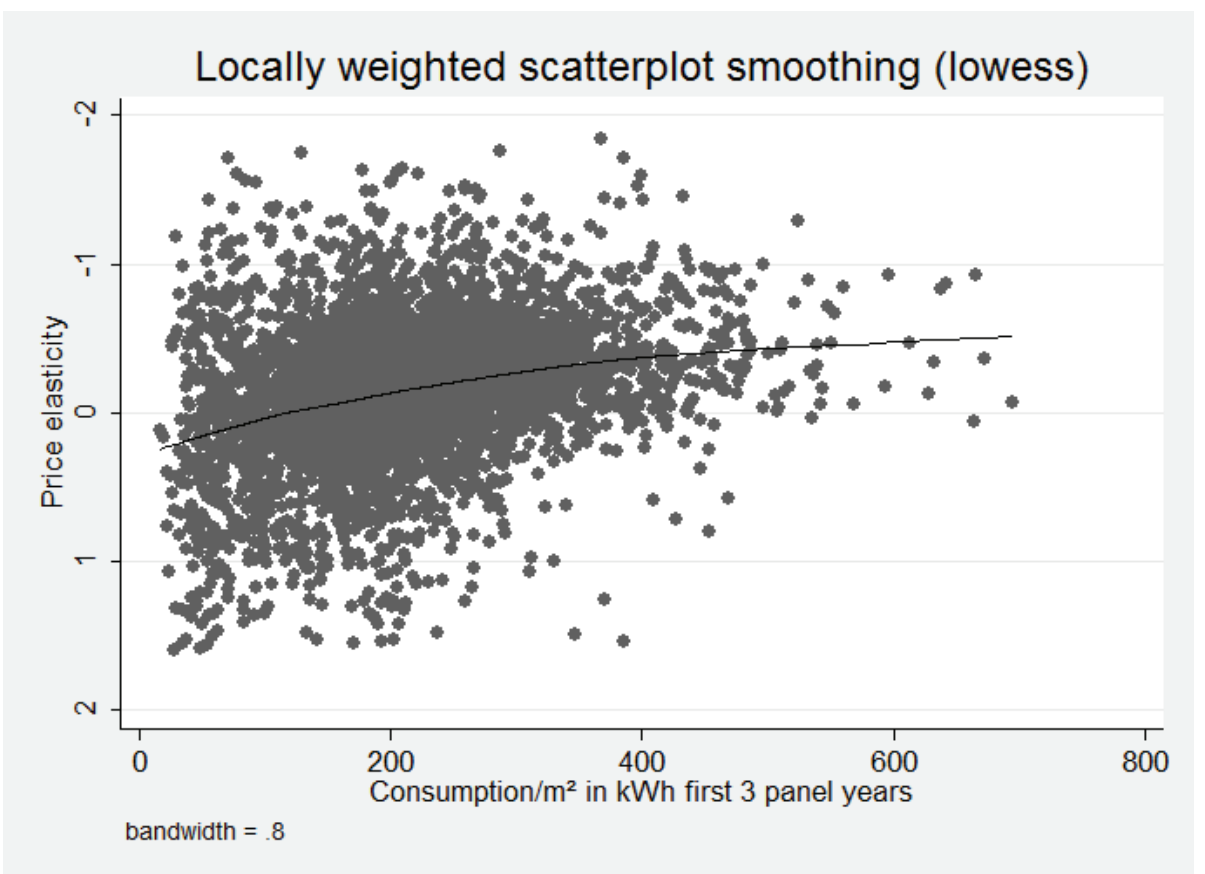

Figure 2. Locally weighted scatterplot smoothing (lowess) for the price elasticity subject to the household's consumption $/ \mathrm{m}^{2}$ in $\mathrm{kWh}$ for the first 3 panel years (GSOEP, 2015)

Figure 3 and 4 further demonstrates how the heating consumption developed between 1998 and 2012 for tenants and owners as well as for residential and detached buildings. ${ }^{6}$

\footnotetext{
6 Annual energy prices vary stronger than the heating costs reported by the households. Peaks or drops in consumption therefore arise from the estimation of the household's consumption by dividing the reported costs with the annual energy prices with respect to the type of heating.
} 


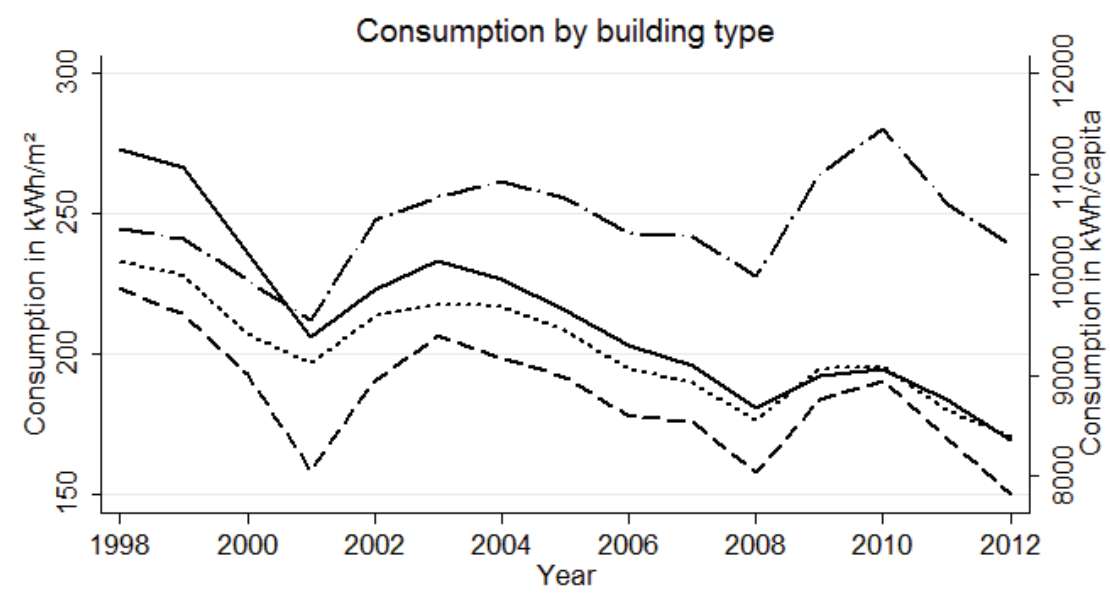

- Consumption in $\mathrm{kWh} / \mathrm{m}^{2}$ Residential Build.

.......... Consumption in $\mathrm{kWh} / \mathrm{m}^{2}$ Detached Build.

- - - - Consumption in kWh/capita Residential Build.

- - - . Consumption in kWh/capita Detached Build.
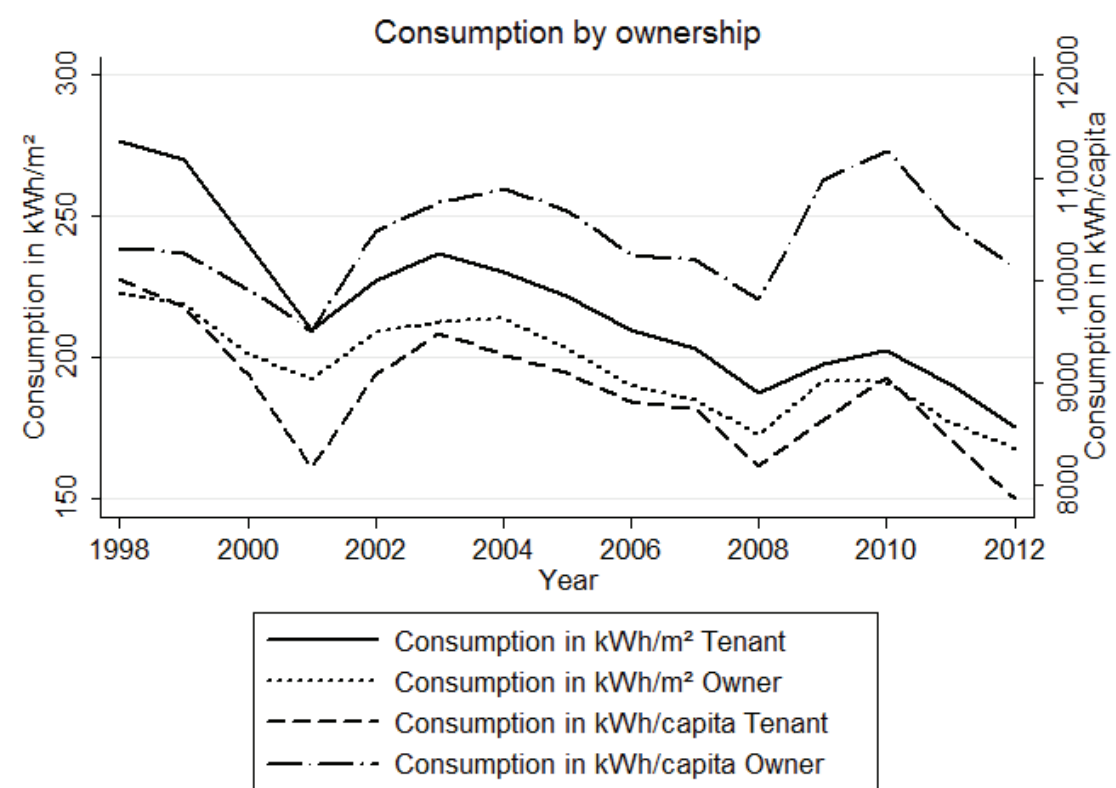

Figure 3. and 4. Consumption by ownership and building type from 1998-2012 (GSOEP, 2015) 
It is apparent how the consumption for tenants in figure 3 looks nearly the same as the consumption for inhabitants of residential buildings in figure 4. The same holds for owners and detached buildings. As seen in the OLS regression, tenants have higher initial consumptions in $\mathrm{kWh}$ per square meter compared to owners. Residential buildings also have the highest consumption in $\mathrm{kWh}$ per square meter until the year 2001. Looking at the consumption in $\mathrm{kWh}$ per capita, however, the initial consumption level is higher for owners than for tenants, just like the initial consumption level per capita of inhabitants of detached buildings is higher than the consumption per capita of residential building inhabitants. Moreover, the per capita consumption for homeowners and inhabitants of detached buildings is the only one not decreasing over the time span considered here. This is partly attributable to higher per capita living spaces. ${ }^{7}$ In comparison to homeowners, tenants started from a high initial consumption but decreased their consumption greater than homeowners.

The rising rather than declining consumption per capita for homeowners or inhabitants of detached buildings is especially essential. Regarding policy goals to reduce overall $\mathrm{CO}_{2}$ emissions in the residential sector, the results above indicate that price signals and subsidies seem to fail at least for homeowners and inhabitants of detached houses. This is in line with the fact that there are different refurbishment rates for detached houses and residential buildings in Germany. Concerning the energetic refurbishment rate of buildings, they are especially higher in residential buildings than in detached houses (Stieß et al., 2010). This is reinforced by the fact that by refurbishing, owners of smaller residential buildings achieved energy efficiency increases of approximately 15\% whereas owners of large residential buildings achieved energy efficiency increases of $32 \%$. Rosenschon et al. (2011) explain this result with the advantage for owners of large residential buildings with regard to more experience with energetic refurbishments. In line with Coase's (1937) theory, owners of large residential buildings have lower transaction costs and higher economies of scale effects. Owners of small residential buildings also often lack the solvency to invest in their building. Furthermore, the payback period often exceeds the owner's life expectancy (Stieß et al., 2010; Rosenschon et al., 2011). The studies from Madlener and Hauertmann (2011) and Meier and Rehdanz (2010), as well as this study, did not control for the refurbishment of a building, as this data is not available. If residential buildings were refurbished to a greater extent than detached houses in the considered period, occupants of residential buildings, i.e. mostly tenants, reduced their energy consumption more than occupants of detached houses. Thus, the higher price elasticity of tenants could also be an effect of the higher refurbishment rates of residential buildings. Figure 3 and 4 support this thought.

Moreover, the surface-to-volume ratio (sa:v) might be another factor, i.e. in buildings with a small sa:v ratio (residential buildings), the warmth diffuses to a larger proportion due to ventilation than in detached houses, where a larger share of the total heat loss diffuses through the surface (large sa:v ratio) (Bettencourt et al., 2007). Reducing the ven-

7 Per capita living space for homeowners increased $14 \mathrm{~m}^{2}$ on average from 1998 to 2012. The average household size of homeowners was 2.85 in 1998 and 2.38 in 2012 (GSOEP, 2015). 
tilation (shorter periods or less frequent ventilation) therefore leads to higher savings in residential buildings than in detached houses. Also, reducing the ventilation normally goes along with a smaller loss in comfort compared to reducing the indoor temperature. Thus, if all households would seek to reduce the heating energy demand by reducing the ventilation, the occupants of residential buildings, i.e. mostly tenants, would achieve higher savings in relation to their initial value than occupants of detached houses. Unfortunately, these two thoughts cannot be tested with the available data.

\section{DISCUSSION AND POLICY IMPLICATIONS}

Until now the counterintuitive differences in the price elasticities of tenants and home owners were not explained in the literature. Tenants were found to have higher price elasticities than owners. After laying out why one would expect this to be the other way around, i.e. owners having higher elasticities than tenants, we searched for aspects which could explain the finding.

We postulated that the effect is partly generated by the fact that owners and tenants are distributed unequally to building and household types. This implies varying initial heating consumption and levels of energy expenditures. We assumed that households with high initial consumptions and / or high energy expenditures should have higher price elasticities from a microeconomic point of view. Furthermore, we associated different levels of domesticity and thus varying possibilities of reducing heating costs by reducing the indoor temperature according to the building and heating types.

In order to test our hypothesis, we performed fixed effects and OLS regressions with German panel data from the GSOEP. We obtained similar results compared to other studies, i.e. tenants having higher elasticities than owners. Moreover, the price elasticity according to the fixed effects regression varies for various building and household types. With the objective to further explain these findings, the price elasticity for each household was computed and used as a dependent variable in an OLS regression. The OLS regression supports the preliminary results from the fixed effects regression for different building types and household types: The differences in price elasticity are mostly not due to different attitudes towards rising energy prices between tenants and homeowners. Rather this effect is generated by a set of characteristics differing between tenants and homeowners, such as domesticity and initial levels of heating energy consumption and expenses, which themselves are linked to different building types and to the ownership structure. We showed that tenants had higher initial heating energy consumption per square meter than homeowners, but reduced their consumption per square meter more than homeowners, who started at a lower level. This explains the differing elasticities, which could be the outcome of differing refurbishment rates and effects resulting from building physics, i.e. varying effects on energy saving when reducing ventilation, for instance. Due to missing data, we could not test these assumptions.

Even though the results in our study are in line with those from other studies, the estimation of the household consumption lacks accuracy. More precise data, especially 
figures for the real heating consumption of households according to their bills, would be preferable. Also, more information on the domesticity, e.g. information about the presence at home for each household member, would facilitate the measurement of domesticity levels.

One policy implication can be drawn from the results of this study. As homeowners, respectively inhabitants of detached houses, have comparatively small heating energy price elasticities, reduction policies should have a stronger focus on this group. This is not only important because they were found to have smaller elasticities, but also because they consume more energy per capita for space heating due to larger dwelling sizes. The fact that dwelling sizes are steadily increasing while household sizes are decreasing in the case of homeowners makes this group a highly relevant target to tackle when seeking to reduce $\mathrm{CO}_{2}$ emissions in the residential sector.

There are already a wide variety of consulting services for owners of detached houses seeking to invest in their home in Germany. The fact that refurbishment nevertheless rarely takes place for this group is often due to a lack of money, expertise, but also longterm perspective (Stieß et al., 2010). Old detached houses which are often inhabited by senior citizens living alone should therefore be especially assisted. For assistance, we would propose the foundation of refurbishment trusts: Such a trust would undertake all necessary investment and management for refurbishment and the homeowner would give the money for the resulting energy savings to the trust in return. Whilst nothing really changes for the owner with regard to heating expenses, this would be beneficial for the environment as energy could be saved and $\mathrm{CO}_{2}$ emissions would be reduced.

\section{REFERENCES}

Baker, P., Blundell, R., Micklewright, J. (1989). Modelling Household Energy Expenditures Using Micro-data. Economic Journal, 99(397): 720-738.

Bettencourt, L. M.A., Lobo, J., Helbing, D., Kühnert, C., West, G. B. (2007). Growth, innovation, scaling, and the pace of life in cities. Proceedings of the national academy of sciences (PNAS), 104(17): 7301-7306.

BMWi (2014). Zweiter Monitoring-Bericht "Energie der Zukunft". Langfassung. Berlin: Bundesministerium für Wirtschaft und Energie. URL: http://www.bmwi.de/DE/ Mediathek/publikationen,did=634268.html (May 10, 2016).

Coase, R. H. (1937). The Nature of the Firm. Economica, 4(16), 386-405.

Engel, E. (1881). Das Rechnungsbuch der Hausfrau und seine Bedeutung im Wirtschaftsleben der Nation. Berlin: Simion.

Eurostat (2016). Heating degree-days by NUTS 2 regions - annual data (nrg_esdgr_a). Luxemburg: Statistical office of the European Union.http://ec.europa.eu/eurostat/ web/energy/data/database (04.05.2016).

Gossen, H. H. (1854). Entwicklung der Gesetze des menschlichen Verkehrs, und der daraus fließenden Regeln für menschliches Handeln. Braunschweig: Vieweg. 
Guertin, C., Kumbhakar, S. C., Duraiappah, A.K. (2003). Determining Demand for Energy Services: Investigating income-driven behaviours. Winnipeg, Manitoba: International Institute for Sustainable Development (IISD).

Halvorsen, B. and Larsen, B. M. (2001). The flexibility of household electricity demand over time. Resource and Energy Economics, 23: 1-18.

Hanemann, M., Labandeira, X., Labeaga, J.M., López-Otero, X. (2013). Energy Demand for Heating: Short Run and Long Run. Economics for Energy Working Paper 07/2013.

Kossmann, B., von Wangenheim, G., Gill, B. (2016). Wege aus dem Vermieter-Mieter-Dilemma bei der energetischen Modernisierung: Einsparabhängige statt kostenab-abhängige Refinanzierung. Policy Paper. Lokale Passung and EnWorKS.

Madlener, R. and Hauertman, M. (2011). Rebound Effects in German Residential Heating: Do Ownership and Income Matter? FCN Working Paper No. 2/2011. Aachen: Rheinisch-Westfälische Technische Hochschule Aachen (RWTH).

Meier, H., and Rehdanz, K. (2010). Determinants of residential space heating expenditures in Great Britain. Energy Economics 32(5): 949-959.

Nässén, J. (2014). Determinants of greenhouse gas emissions from Swedish private consumption: Time-series and cross-sectional analyses. Energy 66: 98-106.

Nesbakken, R. (1999). Price sensitivity of residential energy consumption in Norway. Energy Economics 21(6): 493-515.

OECD (2012). Divided We Stand: Why Inequality Keeps Rising. OECD Publishing.

Rosenschon, S., Schulz, C., Michelsen, C. (2011). Energetische Aufwertung vermieteter Mehrfamilienhäuser: Die kleinen Wohnungsanbieter tun sich schwer - Auswertungen auf Grundlage des ista-IWH-Energieeffizienzindex. Wirtschaft im Wandel 4:161-168.

RWI (2013). Erhebung des Energieverbrauchs der privaten Haushalte für die Jahre 20092010. Essen: Rheinisch-Westfälisches Institut für Wirtschaftsforschung (RWI). URL: http://www.rwi-essen.de/media/content/pages/publikationen/rwi-projektberichte/PB_Energieverbrauch-priv-HH-2009-2010.pdf (May 10, 2016).

Schwabe, H. (1966). Das Verhältnis von Miete und Einkommen in Berlin. Ludwigshafen: Hausbau Rheinland-Pfalz.

Schubert, J., Wollbring, T., Gill, B. (2012). Settlement Structures and Carbon Emissions in Germany: The Effect of Social and Physical Concentration on Carbon Emissions in Rural and Urban Residential Areas. Environmental Policy and Governance, 23(1): 13-29.

Stieß, I., van der Land, V., Birzle-Harder, B., Deffner, J. (2010). Handlungsmotive, -hemmnisse und Zielgruppen für eine energetische Gebäudesanierung. Project report, commissioned by the Federal Ministry of Education and Research. Frankfurt am Main.

Varian, H., (2010). Intermediate Microeconomics. A Modern Approach. New York/London: W. W. Norton.

Van Raaij, W. F., Verhallen, T. M. M. (1983). A behavioral model of residential energy use. Journal of Economic Psychology, 3(1): 39-63. 
Wolff, A., Schubert, J., Gill, B. (2017). Risiko energetische Sanierung? Untersuchungen zur Differenz von Energiebedarf und -verbrauch und ihre Auswirkungen auf einkommensschwache Haushalte. In: Grossmann, K., Schaffrin, A., Smigiel, C. (eds.), Energie und soziale Ungleichheit: Zur gesellschaftlichen Dimension der Energiewende in Deutschland und Europa (pp. 611-634). Wiesbaden: Springer VS.

Wooldridge, J. (2013). Introductory Econometrics. A Modern Approach. Mason/Ohio: South-Western Cengage Learning. 


\title{
POTROŠNJA GRIJANJA U STAMBENOM SEKTORU: SLABA ELASTIČNOST POTROŠNJE KOD KUĆEVLASNIKA
}

\author{
Ines Weber i Bernhard Gill
}

\begin{abstract}
Sažetak
U ovom su radu predstavljeni rezultati istraživanja o elastičnosti troškova zagrijavanja domaćinstava $u$ Njemačkoj. Pri interpretaciji rezultata koriste se i podaci iz prijašnjih studija o razlikama u elastičnosti potrošnje kod kućevlasnika i zakupaca. Koristeći panel-podatke iz GSOEP-a (Njemački socio-ekonomski panel), pomoću metode fiksnih učinaka i OLS regresije istražili smo faktore o kojima ovisi razlika izmecu kućevlasnika i zakupaca u elastičnosti cijene grijanja. Naši rezultati upućuju na zaključak da elastičnost cijene grijanja uvelike ovisi o početnoj različitoj količini potrošnje kod kućevlasnika i zakupaca.

Bolje razumijevanje načina na koji domaćinstva reagiraju na povećanje cijena energenata, uzimajući u obzir razlike između vrsta domaćinstava te početnu količinu potrošnje i iznos troškova, korisno je u oblikovanju ciljanih mjera za smanjenje emisija $\mathrm{CO}_{2}$. Pokazali smo da je najviša potrošnja energije za grijanje kod vlasnika kuća, i to samostojećih kuća, śto se kroz posljednjih nekoliko godina joś i dodatno pové́avalo. To dovodi do slabije elastičnosti cijena za one koji posjeduju vlastitu kuću u odnosu na zakupce. Politika redukcije stoga treba biti snažnije usmjerena na kućevlasnike samostojećih kuća.
\end{abstract}

Ključne riječi: grijanje prostora, elastičnost cijena, Njemačka, agencijska teorija, poticaji za štednju, poticaji za obnovu

\section{HEIZUNGSVERBRAUCH IM WOHNSEKTOR: EINE SCHWACHE VERBRAUCHSELASTIZITÄT BEI HAUSEIGENTÜMERN}

\section{Ines Weber und Bernhard Gill}

\section{Zusammenfassung}

In der vorliegenden Arbeit werden die Forschungsergebnisse zur Kostenelastizität der Raumbeheizung von Haushalten in Deutschland dargestellt. Bei der Interpretation der Ergebnisse werden auch Daten as den vorherigen Studien über Unterschiede bei der Verbrauchselastizität zwischen Hauseigentümern und Mietern genutzt. Mit Hilfe der Daten vom GSOEP (German Socio-Economic Panel), der Methode mit fixen Effekten und der OLS-Regression haben wir die Faktoren untersucht, von denen der Unterschied zwischen Hauseigentümern und Mietern bei der Preiselastizität der Heizung abhängt. Unsere Resultate weisen auf den Schluss hin, dass die Preiselastizität der Heizung im großen Maße vom unterschiedlichen Anfangsverbrauch bei Hauseigentümern und Mietern abhängt.

Das Verständnis der Reaktion von Haushalten auf die Energenten-Preissteigerung, mit Rücksicht auf die unterschiedlichen Arten der Haushalte, den Anfangsverbrauch und die Kostensumme, ist nützlich bei der Gestaltung von gezielten Maßnahmen zur Reduktion der CO2 Emissionen. Wir haben gezeigt, dass Hauseigentümer und zwar diejenigen von Einfamilienhäusern den höchsten Heizungsverbrauch haben, was sich in den letzten Jahren noch gesteigert hat. Das bringt zu einer schwächeren Preiselastizität für Hauseigentümer im Vergleich zu den Mietern. Die Reduktionspolitik sollte sich deshalb stärker auf Eigentümer von Einfamilienhäusern ausrichten.

Schlüsselwörter: Raumheizung, Preiselastizität, Deutschland, Agenturtheorie, Sparsubventionen, Renovierungssubventionen 